\title{
Challenging the transitional justice paradigm: addressing ESRs violations in transitional justice processes
}

\author{
Desafiando el paradigma de la justicia transicional: \\ abordando las violaciones de derechos económicos \\ y sociales en los procesos de justicia de transición
}

\author{
Laura GARCÍA MARTÍN \\ Investigadora Postdoctoral y \\ Profesora Asistente de Derecho internacional público \\ Universidad de Sevilla \\ Igarcia17@us.es
}

RECIBIDO EL 25 DE JULIO DE 2018/ ACEPTADO EL 16 DE OCTUBRE D 2018

\begin{abstract}
The economic and social dimension of transitional justice has been largely ignored in favour of traditional emphasis on violations of civil and political rights. While early transitional justice processes mainly focused on criminal prosecutions for bodily integrity violations, socioeconomic issues, including economica and social rights (herein ESRs) violations, were seen just as part of background. However, scholarship and practitioners are increasingly calling to include ESRs violations in transitional justice processes. Indeed, economic and social conditions are frequently linked to human rights abuses, often constituting a cause, means or consequence of conflict and authoritarianism. Including the assessment of ESRs violations as an issue for transitional justice might serve the purpose of establishing a more comprehensive understanding of the root causes of past human rights violations as well as to facilitate the pathway to achieve a sustainable peace.
\end{abstract}

Keywords: transitional justice, human rights, economic and social rights, development, peacebuilding.
Resumen: La dimensión económica y social de la justicia de transición ha estado tradicionalmente relegada a un segundo plano, tomando prioridad en este sentido las violaciones de derechos civiles y políticos. Mientras que los primeros procesos de justicia de transición se enfocaban en juicios penales por crímenes relacionados con la integridad física personal, las cuestiones de carácter socioeconómico, así como las violaciones de derechos económicos y sociales, se consideraba simplemente como parte del contexto en el que aquellos crímenes tenían lugar. No obstante, tanto la academia como los especialistas sobre el terreno abogan hoy en día para que se incluyan las violaciones de derechos económicos y sociales en los procesos de justicia de transición. De hecho, las violaciones de derechos humanos están frecuentamente ligadas a unas circunstancias socioeconómicas negativas específicas, bien constituyendo estas la causa, medio o consecuencia del conflicto. Por lo tanto, incluir apropiadamente una evaluación de las violaciones de derechos económicos y sociales en los procesos de justicia de transicion podría contribuir al establecimiento de las causas subyacentes de las violaciones de derechos humanos que tuvieron lugar en el pasado, así como facilitaría el camino para conseguir una paz duradera.

Palabras clave: justicia de transición, derechos humanos, derechos económicos y sociales, desarrollo, construcción de paz.

Sumario: I. INTRODUCTION. II. TRADITIONAL INVISIBILITY OF ESRS IN TRANSITIONAL JUSTICE PROCESSES. III. ADDRESSING ESRS IN TRANSITIONAL JUSTICE PROCESSES. III.1. Truth. III.2. Justice.III.3.Reparations. III.4. Institutional reform. IV. CONCLUDING THOUGHTS. LIST OF REFERENCES 


\section{INTRODUCTION}

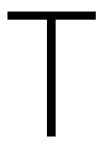

ransitional justice programmes have been traditionally focused on civil and political rights (CPRs) as well as bodily integrity violations, largely ignoring therefore those related to economic and social rights (ESRs). This last set of rights and socioeconomic elements of conflict or authoritarianism have been generally relegated to the background issues. ${ }^{1}$ Socioeconomic grievances however often appear as relevant aspects to the past violent dynamics, so considering them can potentially provide a deeper understanding of the root causes of conflict, as well as helping to reduce the chances of recurrence in the future. ${ }^{2}$

Indeed, many conflicts and dictatorial regimes are often fueled by socioeconomic injustices, and frequently involve significant ESRs violations. Yet riots in Tunisia and Egypt that ultimately led to large-scale violence were based on expressed socioeconomic concerns, such as unemployment and corruption. ${ }^{3}$ Likewise, pursuing neo-liberal economic policies by most of the military regimes in Latin America was found to be closely linked to violations of ESRs, particularly regarding trade unionists and leftist activists who became the main target of repression.

Notwithstanding these considerations, many commentators advocate caution about including ESRs within transitional justice strategies, arguing that addressing ESRs in such contexts could jeopardise the whole transitional justice programme, being too broad and ambitious. Similarly, some authors

1 See i.e. Sharp, D.N, «Addressing Economic Violence in Times of Transition: Toward a Positive-Peace Paradigm for Transitional Justice», Fordham International Law Fournal, vol. 35 (2012); See also, Roth-ArriaZA, N., «Why was the Economic Dimension Missing for So Long in Transitional Justice? An Exploratory Essay», in H. Verbitsky and J. P. Bohoslavsky (ed.), The Economic Accomplices to the Argentine Dictatorship. Outstanding Debts, Cambridge University Press, 2015, pp. 19-28; CALVET MaRTíNEZ, E., «La exigibilidad de los derechos económicos, sociales y culturales en situaciones de post-conflicto y en procesos de justicia transicional», in J. Bonet Pérez and R. A. Alija Fernández (ed.), La exigibilidad de los derechos económicos, sociales y culturales en la Sociedad Internacional del siglo XXI: una aproximación jurídica desde el Derecho internacional, Marcial Pons, 2016, p. 199.

2 Szoke-Burke, S., «Not Only «Context': Why Transitional Justice Programs Can No Longer Ignore Violations of Economic and Social Rights», Texas International Law Fournal, vol. 50, no. 3, 2015, pp. 465-494.

3 See Muñoz Nogal, E.; Gómez Isa, F., «iPan, Libertad, Justicia Social! Las revueltas populares de Túnez y Egipto y la defensa de derechos económicos y sociales», in J. Bonet Pérez and R. A. Alija Fernández (ed.), La exigibilidad de los derechos económicos..., op. cit., pp. 219-241. 
have expressed concerns about the suitability of existing transitional justice mechanisms and tools to do this task. ${ }^{4}$

Regarding the structure, the next section of this article analyses the current theoretical debate about including ESRs violations in transitional justice. It then seeks to refute concerns about their inclusion by outlining that some conceptual confusion occurred when trying to address ESRs in transitional justice processes. ${ }^{5}$ Certainly, ESRs are just one element of the socioeconomic dimension of transitional justice and state failures to respect and protect them can be relatively straightforward addressed within the existing transitional justice tools. ${ }^{6}$ Indeed, addressing socioeconomic issues and ESRs violations in transitional justice strategies can provide crucial insight into the root causes of past violence while contributing to reduce the chances of recurrence in the future. Whereas it would be unrealistic to expect that the inclusion ESRs violations will resolve the full extent of the socioeconomic challenges at stake in post-conflict or post-authoritarian situations, this paper contends that addressing specific ESRs depending on the particular context, could contribute towards such wider goals.

Having examined the transitional justice scholarship debate, this paper then also explores how ESRs can be potentially addressed by the existing transitional justice mechanisms, providing real examples of how it has already been done in specific transitional justice processes. Mechanisms will be considered in this core section according to their transitional justice process belonging, namely, truth, justice, reparations and and institutional reform. Finally, last section presents the conclusions and suggestions for the way forward.

\section{Traditional Invisibility of ESRs in Transitional Justice Processes}

Together with international criminal law and international humanitarian law, international human rights law remains the most frequently invoked legal framework of transitional justice scholarship and policymaking. However,

4 See Duthie, R., «Transitional Justice, Development, and Economic Violence», in fustice and Economic Violence in Transition, Dustin N. Sharp (ed.), Springer, 2014, pp. 165-201.

5 SCHMid, E.; Nolan, A., «Do No Harm'? Exploring the Scope of Economic and Social Rights in Transitional Justice», The International fournal of Transitional fustice, vol. 27, no. 3, 2014, pp. 362-382.

$6 \quad$ Ibid., p. 375. 
transitional justice -in both its institutional and scholarly dimensions- has historically focused on violations of CPRs and, hence, excluded socioeconomic aspects of conflict and authoritarianism, such as violations of ESRs, structural violence, and development. ${ }^{7}$

There are several reasons why transitional justice has historically tended to neglect economic and social wrongs. ${ }^{8}$ On the one hand, transitional justice has been heavily influenced by human rights law and its longstanding bias towards CPRs, being this last set of rights traditionally considered as more justiciable rights. ${ }^{9}$ Traditional conceptions considered that identifying violations, perpetrators, and remedies was easier when it comes to CPRs. Similarly, the notion of 'liberal peacebuilding' has been often applied in transitional contexts, which supports the idea that political and economic liberalisation promotes sustainable peace, based on the thinking that market democracies are less likely to get into conflict. Following this neoliberal approach, transitional justice has been largely ignoring ESRs violations.

In addition, criminal justice, and particularly, international criminal law, has profoundly influenced the rise of transitional justice as a field. International criminal law mostly focuses on CPRs linked to bodily integrity, such as torture and killings, and it emphasizes individual criminal responsibility rather than structural causes of conflict or repression. ${ }^{10}$ Indeed, limitations imposed by a focus on prosecutions also explain why the historical focus of transitional justice has not either been on economic actors. ${ }^{11}$ Furthermore, historical context in which the field emerged helps to explain why socioeconomic concerns were left outside the bounds of transitional justice. Given that initial transitions were conceived as short-term projects, socioeconomic issues were seen as new tasks for successor regimes in the post-transition period.

7 Indeed, socioeconomic considerations are almost totally absent in two of the most relevant works on transitional justice, such as TeITEL, R., «Transitional Justice Genealogy», Harvard Human Rigths Fournal, vol.16, no.1, 2003, pp. 69-94; ElSTER, J., Closing the Books: Transitional Fustice in Historical Perspective, Cambridge, Cambridge University Press, 2004.

8 For a further analysis on the causes see WALDORF, L., «Anticipating the Past: Transitional Justice and Socio-Economic Wrongs», Fournal of Social \& Legal Studies, vol. 21, no.2, 2012, pp. 171-186.

9 CAHILl-RIPleY, A., «Foregrounding socio-economic rights in transitional justice: realising justice for violations of economic and social rights», Netherlands Quarterly of Human Rights, vol. 32, no. 2, 2014, pp. 183-213.

10 Miller, Z., «Effects of invisibility: In search of the «economic' in transitional justice», International Fournal of Transitional fustice, vol.2, no. 3, 2008, pp. 266-291.

11 See Roth-ARRIAZA, supra note 1 at 23. 
On the other hand, mandates of both tribunals and truth commissions have traditionally relied heavily upon the realisation of human rights in the new transitional state, so they have tended almost uniformly to emphasize CPRs rather than socioeconomic ones. Consequently, socioeconomic concerns become doubly reduced, excluded by a focus on legalistic rights discourse first, and, second, left out according to the common preference of human rights mechanisms for CPRs violations. ${ }^{12}$

The well-known Louis Arbour's speech in 2006 in which she advocated for more attention to 'economic and social justice for societies in transition', ${ }^{13}$ marked a turning point in the current debate on economic and social dimensions of transitional justice. Arbour clearly pointed the importance of integrating ESRs into 'the transitional justice framework', as well as highlighting how some specific transitional justice mechanisms have already dealt with these rights. Additionally, Arbour argued that 'violations of civil and political rights are intrinsically linked to violations of economic, social, and cultural rights.' ${ }^{14}$

Several scholars and practitioners heeded Arbour's call. ${ }^{15}$ Rama Mani, for instance, insisted that transitional justice 'will lose credibility in the predominantly impoverished and devastated societies where it operates' if it does not tackle social injustice, corruption, resource exploitation and criminal violence. ${ }^{16}$ Similarly, The International Journal of Transitional Justice devoted a special issue to transitional justice and development in 2008, and the International Center for Transitional Justice published an edited collection on the

12 Mcevoy, K., «Beyond Legalism: Towards a Thicker Understanding of Transitional Justice», Fournal of Law and Society, vol. 34, no.4, 2007, pp. 411-440.

13 Then, the United Nations High Commissioner for Human Rights. Before Arbour's speech, some had already criticised TRCs such as South African one for narrowly focusing on CPRs abuses. ARBOUR, L., «Economic and Social Justice for Societies in Transition», International Law and Politics, vol. 40, no.1, 2007, pp. 1-3.

14 Ibid., pp. 3-7. Additionally, in her speech, Arbour criticised United Nation Former Secretary General Kofi Annan for adopting a narrow formulation of justice in his important 2004 report on transitional justice.

15 See i.e. CARRANZA, R., «Plunder and pain: Should transitional justice engage with corruption and economic crimes?», International Fournal of Transitional fustice, vol. 2, 2008, pp. 310-330; GREADY, P., The Era of Transitional Fustice: The Aftermath of the Truth and Reconciliation Commission in South Africa and Beyond, Routledge, 2010; ŞAHINKAYA, Y., «The expanded scope of Transitional Justice: Addressing Root Causes of Economic, Social and Cultural Rights Violations', Human Rights Review, vol. III, no. 1, 2013, pp. 108-125.

16 MANI, R., «Editorial: Dilemmas of expanding transitional justice, or forging the nexus between transitional justice and development», International fournal of Transitional fustice, vol. 2, 2008, p. 254. 
same topic in 2009. Over the past few years, both scholars and practitioners have been promoting holistic approaches to the field of transitional justice, including potential links between ESRs and development. ${ }^{17}$ Furthermore, UN policy, scholarship and practice in the field of transitional justice have been also influenced by Arbour's speech. For instance, in 2009 the Human Rights Council adopted a resolution that underlined the importance of ensuring that violations of all human rights, including economic, social and cultural rights, are addressed in transitional contexts. ${ }^{18}$

Lately, the complex debate about whether transitional justice should -and could- incorporate economic and social issues has substantially expanded, both in authors' engagement and relevance. Not all scholars and practitioners share positive arguments on the desirability of including socioeconomic concerns in the transitional process. Waldorf, for instance, argued that the 'shift in transitional justice discourse and practice with respect to economic and social rights' is deeply problematic, as he conceives transitional justice as 'inherently short-term, legalistic and corrective', so he argues that it should focus on accountability for gross violations of CPRs. ${ }^{19}$

On the other hand, some commentators have suggested that in order to include ESRs violations and socioeconomic grievances, transitional justice as a field must be rethought. ${ }^{20}$ Given that transitional justice has historically focused on CPRs violations, they content that the inclusion of ESRs would require a paradigm shift within the entire field. In this sense, some authors go beyond considering the notion of 'transformative justice' as an alternative for addressing socioeconomic issues in transitional justice.

Lambourne, for instance, proposes a transformative model of transition which requires a transformation in social, economic and political structures and relationships. ${ }^{21}$ Accordingly, several scholars have called on including so-

17 See i.e. De GreIfF, P.; Duthie, R., Transitional fustice and Development: Making Connections, New York, Social Science Research Council, 2009.

18 «Human Rights Council Resolution on Transitional Justice and Human Rights», UN Doc. A/ HRC/ RES/12/11 (12 October 2009), para. 18 and preamble.

19 See WALDORF, supra note 8 at 171.

20 See i.e. Haldemann, F.; Kouassi, R., «Transitional Justice without Economic, Social and Cultural Rights?», in Economic, Social, and Cultural Rights: Contemporary Issues and Challenges, eds. Eibe Riedel, Gilles Giacca, and Christophe Golay (eds), Oxford University Press, 2014, pp. 498-514; See also OrÉ AgUILAR, G.; GÓmEZ IsA, F. (eds.), Rethinking Transitions: Equality and Social fustice in Societies Emerging from Conflict, Intersentia, 2011.

21 Lambourne concludes that in addition to accountability or legal justice, attention needs to be paid to the psychosocial processes, socioeconomic conditions and political context in order for 
cial justice in transitional justice processes. Supporters of this theory argue that, to have an actual impact on victims' positions, transitional justice strategies need to integrate mechanisms to address all human rights violations, including those related to ESRs. But transformative justice has also faced criticism and has been questioned for being thin on conceptual inspiration and making a limited impact in practice. In fact, some commentators have argued that this theory seeks to fundamentally change the priorities of transitional justice by challenging 'unequal and intersecting power relationships and structures of exclusion at both the local and the global level'.22 Others are concerned about transitional justice becoming analytically overstretched and impractical if it tries to include too much, so goals of social justice may be better left to other fields, such as development policies. ${ }^{23}$

Duthie, for instance, argues that even if transitional justice as a field should become 'development sensitive', it is debatable whether such linkages would be transformative enough. ${ }^{24}$ In this same line, it may be questioned whether such transformative initiatives will promote social unrest in already unstable societies in transition. Be that as it may, scholarship and practitioners have been lately calling for a broad framework, moving towards the integration of socioeconomic grievances and promotion of social justice in transitional justice strategies. As McGonigle notes, however, this call is still largely aspirational and significant empirical data is needed..$^{25}$

Concerning this debate, Schmid and Nolan have usefully pointed out that when employing rights language, the current debate on the economic and social dimensions of transitional justice frequently suffers from terminological and conceptual confusion. ${ }^{26}$ They argue that the distinction between ESRs and broader socioeconomic issues often gets lost, so an accurate understanding of ESRs and the obligations they impose is needed. According to them, these

transitional justice to support peacebuilding. LAmbouRnE, W., «Transformative justice and Peacebuilding», in S. Buckley-Zistel, T. Koloma Beck, C. Braun, and F. Mieth (eds.), Transitional fustice Theories, Routledge, 2014, pp. 19-39.

22 GREADY, P.; Robins, S., «From Transitional to Transformative Justice: A New Agenda for Practice', International Fournal of Transitional Fustice, vol 8, no. 3, 2014, p. 347.

23 McGonigle LeYH, B., «The Socialisation of Transitional Justice: expanding justice theories within the field», Human Rights and International Legal Discourse, no.1, 2017, pp. 83-95.

24 DuthIE, R., «Towards a Development-sensitive Approach to Transitional Justice», International Fournal of Transitional fustice, vol.2, no.3, 2008, pp. 292-309.

25 MCGonigLe supra note 23 at 94

26 SCHMID and NOLAN supra note 5 at 362. 
misconceptions about the legal framework led many commentators to conclude that inclusion of ESRs needs to rethink transitional justice as a whole. Certainly, ESRs are just one aspect of the socioeconomic dimension of transitional justice and their inclusion is perfectly conceivable. Indeed, addressing many violations of ESRs can be relatively straightforward, particularly those related to states' obligations to respect and protect. ${ }^{27}$ While determining the full scope of the state's maximum resources available may require a complex analysis, assessing data on ESRs enjoyment across society is much clearer. Additionally, there are some ESRs rights that do not require significant resources but the States respect and protection, and therefore, they should be implemented immediately. Furthermore, ESRs obligations are also increasingly justiciable, as they have been enshrined in some State consitutions and regional human rights regimes, ${ }^{28}$ and acknowledging state failures to respect and protect can contribute to reinforce such State obligations.

On the contrary, ignoring ESRs violations could be regarded as allowing impunity, which might aggravate violence and result in a new conflict. Transitional justice thus will not be truly effective if violations of ESRs continue to be disregarded or limited to the background of conflict or repression. Selecting and prioritising which particular ESRs should be considered would ultimately depend on the specific circumstances, including the nature of past violations as well as the resource constraints of transitional justice institutions. ${ }^{29}$ Most likely, some specific ESRs concerns would require long-term policy design and implementation, and may therefore not be conveniently covered by transitional justice mechanisms. Conversely, there would be others discrete and remediable enough to be properly addressed by transitional justice strategies, as it will be evidenced in next section.

However, although transitional justice should no longer ignore ESRs violations, this author is equally awared that transitional justice mechanisms would not solve by its own means the consequences of those violations. While it would be naive to expect that the inclusion of ESRs will resolve the full ex-

27 Ibidem.

28 See for instance, African Charter on Human and Peoples' Rights, adopted 27 June 1981, entered into force 21 October 1986, reprinted in ILM 21 (1982) 59, art. 19(1), O.A.U. Doc. CAB/ LEG/67/3 rev. 5, arts. 14 (right to property), 15 (right to work), 16 (right to health), 21 (right to free disposal of wealth and natural resources); Association of South East Asian Nations [ASEAN], ASEAN Human Rights Declaration, 21st Summit (Nov. 19, 2012), arts. 27 (right to work), 28 (right to adequate standard of living), 29 (right to health), 30 (right to social security).

29 See SZOKE-BuRKE supra note 2 at 473. 
tent of the socioeconomic challenges at stake in post-conflict or post-authoritarian contexts, it that does not mean that properly addressing them could not contribute towards such broader goals. However, this author argues that in order to achieve social justice and to alleviate structural poverty and marginalization, transitional justice strategies should be designed and implemented alongside with development programmes, so they can work together in the area of socioeconomic rights to improve their enjoyment in transitional contexts. ${ }^{30}$

Be that as it may, this new holistic and inclusive interpretation of transitional justice has been taken up by the United Nations ${ }^{31}$ and the European Union $^{32}$ at institutional level. Although initiatives in this sense have not completely changed the traditional paradigm of transitional justice, they endorse greater emphasis on ESRs violations in transition. Indeed, the Office of the UN High Commissioner produced in 2014 a report about how to better address ESRs through the existing mechanisms in transitional justice processes. ${ }^{33}$ Notably, this document called for more sustained and detailed research in the area of transitional justice, root causes of conflict and large-scale violations of ESRs. On the other hand, many truth commissions have begun to examine ESRs and expanded their scope to broader socioeconomic issues, such as those of Sierra Leone and Timor Leste as it will be further examined in next section.

\section{Addressing ESRs in Transitional Justice Processes}

Some traditional transitional justice mechanisms have been already employed to address ESRs in transition, although they have been often fairly limited in scope. Amongst the transitional justice toolbox, it is commonly agreed that Truth Commissions and reparations are the two mechanisms that have gone furthest in handling economic and social wrongs are truth commissions and

30 See in this sense, DE GREIFF, P., «Articulating the Links between Transitional Justice and Development: Justice and Social Integration', supra note 17 at 63.

31 Guidance Note of the Secretary-General on the United Nations Approach to Transitional Justice, March 2010.

32 Council of the European Union, Secretary-General of the European Commission, Joint Staff Working Document: The EU's Framework on support to transitional justice, Doc. SWD 158 final, 7 August 2015.

33 UNHRC Report, «Transitional Justice and Economic, Social and Cultural Rights', HR/ $\mathrm{PUB} / 13 / 5,2014$. 
reparations. This section explores how ESRs can be effectively addressed by transitional justice mechanisms within the framework of the four main processes of the field, namely truth, justice, reparations and and institutional reform. ${ }^{34}$

\section{III.1. Truth}

Within the truth process, Truth and Reconciliation Commissions (TRCs) have lately been considered as suitable instruments for addressing the root causes of conflict or repression and violations of ESRs. ${ }^{35}$ Owing to their often limited mandates, most TRCs have traditionally focused on violations of CPRs, but they have given some attention to the root causes of conflict or repression and therefore, considered issues that affect the enjoyment of ESRs, as has been usually reflected in their conclusions and recommendations. ${ }^{36} \mathrm{In}-$ deed, although TRCs are seldom mandated to expressly address violations of ESRs, they are frequently expected to look at the socio-political context underlying the conflict or repression they examine. However, they have generally failed to investigate fully the socioeconomic background to the conflict or authoritarianism under consideration, to elucidate the structural violence of the past or to mandate significant change.

For instance, the South African Truth and Reconciliation Commission narrowly focused on 'bodily integrity rights' rather than on apartheid economic crimes and their impact on ESRs as this was not part of its mandate. ${ }^{37}$ The

34 Concerning the transitional justice processes see, ALIJA FERNÁNDEZ, R.A., «La multidimensionalidad de la justicia transicional: un balance entre los límites jurídicos internacionales y los límites de lo jurídico», in Impunidad, derechos humanos y justicia transicional, Jordi Bonet Pérez and Rosa Ana Alija Fernández (eds), Universidad de Deusto, 2009, pp. 93-166; Sandoval, C.; FiliPINI, L.; VIDAL, R., «Linking Transitional Justice and Corporate Accountability», in S. Michalowski (ed.), Corporate Accountability in the Context of Transitional Fustice Michalowski, Routledge, 2013, pp. 9-26.

35 Other truth initiatives could also contribute to address ESRs violations. The Truth Trials in Argentina, for instance, registered testimonies on ESRs violations although this information was relegated to the background of the conflict, as the CONADEP also did.

36 HaYner, P. Unspeakable Trutbs: Transitional Fustice and the Challenge of Truth Commissions, Routledge, 2011. See also the «Final Report of South African Truth and Reconciliation Commission», vol.5, conclusions.

37 The South African TRC has been critisised because it could have formally investigated allegations of labour violations within the scope of its mandate. See for instance KOsKA, G., «Corporate accountability in times of transition: the role of restorative justice in the South African Truth and Reconciliation Commission, Restorative Justice», Restorative fustice An International fournal, vol. 4, no.1, 2016, pp. 41-67. 
social, economic and political system of apartheid was largely treated as context to instances of egregious bodily harm that became the TRCs main focus. The South African TRC has been indeed strongly criticised for failing to see apartheid as the fundamental crime or to address the wide range of silent beneficiaries of it. ${ }^{38}$ Similarly, the Argentinian Truth Commission (CONADEP) was mainly tasked to investigate the fate of the disappeared, so socioeconomic elements of repression were simply conceived as part of the context. ${ }^{39}$ In the same vein, Chile's TRC identified socioeconomic conditions as root causes of conflict, but the TRC mandate itself prevented it from properly addressing them. ${ }^{40}$

Conversely, Timor Leste's Commission for Reception, Truth and Reconciliation (known by its Portuguese acronym, CAVR) found that Indonesia's 'authoritarian style of government' and its 'close collaboration with special interests' led it to breach its duty to fulfill ESRs. However, it established that victims of these harms should not be considered to be beneficiaries for reparation, based on feasibility concerns and needs-based prioritisation. ${ }^{41}$ Similarly, final report of the Sierra Leone's Commission also devoted a significant place to the underlying causes of conflict, highlighting corruption and poor governance and natural resources, among others. ${ }^{42}$ To carry out its mandate, the Commission adopted categories of violations, including 'economic violations', such as destruction of property, looting and extortion. ${ }^{43}$ However, the Sierra Leone's TRC did not use relevant concepts such as minimum core obligations in its analysis of ESRs. Very little was done likewise to implement its recommendations to address such violations. ${ }^{44}$

In this same line, the Liberian Truth and Reconciliation Commission's report emphasized poverty, corruption and inequality as underlying causes

38 Mamdani, M. «Reconciliation without Justice», Southern African Review of Books, vol. 46, 1996, pp. 3-5.

39 Its exclusive focus reflected what was believed at the time to be the main methodology of repression, while at the same time there was still hope that some of the disappeared might yet be found alive.

40 LAPLANTE, L. «Transitional justice and peacebuilding: diagnosing and addressing the socioeconomic roots of violence through a Human Rights Framework», The International fournal of Transitional fustice, vol. 2, 2008, pp. 331-355.

41 Chega! The report of the Commission for reception, Truth, and Reconciliation in Timor-Leste. Executive summary, 2006, paras 40-41.

42 Sierra Leone Truth and Reconciliation Commission, «Witness to Truth: Report of the Sierra Leone Truth and Reconciliation Commission», vol. 2. Report Three A, Chapters 1-4, 2004.

43 Ibid., vol. 3 A, chapter. 4, para. 14 and 19.

44 MCgOnigLe LeYH, supra note 23. 
of the conflict, but it did not provide any legal analysis of the violations of ESRs. ${ }^{45}$ Other truth commissions reports such as from Guatemala and Peru addressed the socioeconomic factors behind the conflicts, including dispossession, inequality, exclusion, and even the colonial legacy. Nonetheless, these socioeconomic elements were mostly relegated to the sections on historical background, where they were more easily ignored. In any case, it seems that TRC are progressively including socioeconomic rights within their scope. More recently, the TRC in Colombia expressly includes in its mandate addressing the social impact of the conflict, particularly regarding ESRs. ${ }^{46}$

Some scholars have argued that TRCs should do more to remedy socioeconomic wrongs. Mani, for instance, contends that 'truth commissions should go further than analysis of causes and should propose workable solutions for these (social) injustices'. ${ }^{47}$ Alternatively, Szoke-Burke proposes to include both CPRs and ESRs sets within the mandate of a Truth Commission, or having a separate but related 'arm' charged with making recommendations regarding prevention of ESRs violations. ${ }^{48}$ However, limitations in this sense should also be acknowledged. TRC recommendations are often ignored, not because they are unworkable, but because TRC commissions have traditionally been inherently weak institutions with short lifespans. In fact, successor regimes also frequently evade and delay implementing the reparations programmes recommended by truth commissions or other bodies. ${ }^{49}$ While TRCs offer greater flexibility to collect information and to compose a fuller picture of violent past through inclusion and dialogue, there is the danger of overburdening the mandates, which usually operate with limited resources.

45 Republic of Liberia Truth \& reconciliation Commission consolidated final report, 2009. See also SCHMid, E., «Liberia's Truth Commission Report: Economic, Social, and Cultural Rights in Transitional Justice», Praxis: The Fletcher Fournal of Human Security, vol. XXIV, 2009, pp. 5-28.

46 Amongst other relevant issues, the TRC's mandate also includes gender, children and indigenous peoples concerns regarding the impact of the conflict. The TRC will start its works in November, 2018.

47 RAMA MANI, supra note 16 at 256.

48 SZOKE-BURKe, supra note 2 at 482.

49 Tellingly, only 14 of the 84 transitions between 1970 and 2004 implemented reparations programmes. See Olsen, T.; PAYNe, L.; ReITER, A., «Transitional Justice in Balance: Comparing Processes, Weighing Efficacy», Human Rights Quarterly, vol. 32, no. 4, 2010, pp. 980-1007. 


\section{III.2. Justice}

There have been relatively few attempts at litigation on ESRs violations per se in transitional justice strategies. Instead, most of the transitional processes have focused on abuses committed by States and non-state actors which involve economic harm but not specifically ESRs violations, and which resulted in violations of certain CPRs. ${ }^{50}$ While both criminal and civil justice mechanisms face jurisdictional limitations, they can constitute a useful avenue to address violations of ESRs, as well as the root causes of conflict or repression. Indeed, relevant jurisprudence related to ESRs in transitional justice contexts can be found in the judgments of the Inter-American Court of Human Rights and the International Criminal Tribunal for the Former Yugoslavia, as is further analysed below. It is worth noting likewise that the inclusion of ESRs in state constitutions provides another means of litigation, namely through domestic constitutional claims. ${ }^{51}$

The IACtHR judgement in Ituango Massacres v. Colombia is a good example of how ESRs have been litigated in regional courts. In this case, the petitioners alleged that the State had violated the prohibition of slavery and forced labour, given that some victims were coerced to herd livestock under threat of death. ${ }^{52}$ The Court based its resolution on article 6 of the American Convention on Human Rights in the light of ILO Convention No. 29 concerning Forced or Compulsory Labour, ratified by Colombia in 1969. According to the Court interpretation of those articles, forced labour entails three elements: the menace of a penalty, involuntary labour and State participation or acquiescence. The Court held that all three elements were satisfied in this case

50 LeKHa SRIRAM, C., «Liberal Peacebuilding and Transitional Justice: What Place for Socioeconomic Concerns?» in SHARP supra note 1. Sriram notes that a significant number of cases have been filed under the Alien Tort Claims Act (ATCA) in the United States. Some of those cases resulted in corporations facing civil charges, and in some cases, agreed to settlements for complicity in serious violations of human rights as part of their commercial activities in countries such as Colombia and Myanmar.

51 Such as happened with the Colombian Constitutional Court, which has decided important cases on ESRs in the context of the implementation of the Justice and Peace Law.

52 IACtHR, Ituango Massacres v. Colombia, Preliminary Objections, Merits, Reparations, and Costs, Judgment (ser. C) No. 148 (July 1, 2006). In addition to the executions, many people were forcibly displaced. Furthermore, in Aro, most houses were burned down and cattle and other livestock stolen. For several days, residents of the area were forced to herd cattle without remuneration. Army members imposed a curfew to facilitate the transfer of the stolen livestock without witnesses. 
and consequently found instances of forced labor and violation of the right to property in relation to forcible displacements. ${ }^{53}$

Similarly, international criminal tribunals have successfully prosecuted conduct that violated ESRs. In fact, The Rome Statute includes in its article 7 several underlying offences for crimes against humanity that may incorporate violations of ESRs. ${ }^{54}$ In the case Prosecutor v. Brdanin,${ }^{55}$ for instance, the International Criminal Tribunal for the former Yugoslavia held that 'proper medical care was deliberately withheld from Bosnian Muslims and Bosnian Croats by the Bosnian Serb authorities for the very reason of their ethnicity.' The cumulative effect of this conduct, together with the denial of other fundamental rights, such as the right to employment, freedom of movement and proper judicial process, amounted to persecution as a crime against humanity. ${ }^{56}$ The Krajišnik case also illustrates the relevance of violations of ESRs in the conflict of the former Yugoslavia. ${ }^{57}$ The Chamber found that there had been unfair dismissal of people from public jobs, forced labour, lack of access on equal grounds to public services, inhumane living conditions in detention places, appropriation and plunder of property and destruction of private property. ${ }^{58}$ Furthermore, the Special Court for Sierra Leone has also made findings on crimes against humanity involving infringement of ESRs, specifically, labour rights. Trial Chamber found in Sesay, Kallon and Gbao case, ${ }^{59}$ that forced farming, mining and military training constituted the crime against humanity of enslavement. ${ }^{60}$

On the other hand, former state leaders have been also tried for corruption, such as Hosni Mubarak in Egypt or Alberto Fujimori in Peru, although these have not generally been articulated as violations of specific economic or social rights. Certainly, these sorts of prosecutions are frequently limited

53 Ibid., para. 168 and 183

54 Namely enslavement; deportation or forcible transfer of population; other inhumane acts of a similar character intentionally causing great suffering, or serious injury to body or to mental or physical health; and persecution.

55 ICTY, Prosecutor v. Radoslav Brdanin, No. IT-99-36-T, Trial Chamber, Judgement of 1 September 2004.

56 Ibid., para. 1076.

57 ICTY, Prosecutor v. Momčilo Krajišnik, No. IT-00-39-T, Trial Chamber, Judgement of 27 September 2006.

58 Ibid., paras. 736, 755-756, 757-761, 765-772 and 773-779.

59 SCSL, Prosecutor v. Issa Hassan Sesay, Morris Kallon and Augustine Gbao, No. SCSL-04-15-T, Trial Chamber I, Judgement of 25 February 2009

$60 \mathrm{Ibid}$., paras. 1118-1121, 1215-1217, 1476-1477, 1588-1591, 1414-1443. 
because those who benefited from economic plunder in conflict or under authoritarian rule remain politically powerful or they still are able to retain their spoils. ${ }^{61}$ Therefore, while judicial processes can potentially be a useful tool to address and punish ESRs violations as well as stopping impunity, it might be difficult to prosecute perpetrators when they still maintain signigicant power and influence.

\section{III.3. Reparations}

Reparations are the most victim-centred transitional justice mechanism, as they have the potential to respond more directly to victims' needs and priorities. ${ }^{62}$ In fact, reparations are the field where transitional justice measures might be expected to directly deal with economic issues. However, they are primarily designed in most instances to respond to specific victims who suffered violations of CPRs, or to the needs of affected communities, rather than to address violations of specific economic rights or widespread inequality. ${ }^{63}$ The nature of reparations usually involves the transfer of money or other services that can directly have an impact on victims' socioeconomic position. However, while reparations can be consequently a very useful option for remedying victims of ESRs violations, it also presents limitations to produce social change. ${ }^{64}$ Indeed, redistribution of wealth provided by reparations is often limited in a strikingly narrow manner, in which frequently only victims named by the transitional justice measure are compensated. ${ }^{65}$ This means that specific structural causes of violence and marginatization are often left unaddressed. In any case, while reparations are limited enough to solve by its own systemic problems, they still can play a useful role in rehabilitating victims. Ultimately, development strategies should be designed and implemented together with transitional justice programs to have a substantial impact on structural concerns.

\footnotetext{
61 LEKHA SRIRAM, supra note 50 at 41.

62 UNGA, Basic Principles and Guidelines on the Right to a Remedy and Reparations for Victims of Gross Violations of International Human Rights Law and Serious Violations of International Humanitarian Law, A/RES/60/147 (16 December 2005).

63 RoHT-Arriaza, N., «Reparations and Economic, Social, and Cultural Rights», in SHARP, supra note 1.

64 Roht-Arriaza, N.; Orlovsky, K., «A Complementary Relationship: Reparations and Development», in DE GREIFF AND DUTHIE, supra note 17.

65 Miller, supra note 10 at 283-284.
} 
TRC's reports often make recommendations to States on reparations on the basis of administrative reparation programmes. Some programmes include different forms of reparation that could have an impact on the realization of ESRs, although it should be examined with caution due to implementation and financing problems. Reparations have a limited scope, which means that trying to use them to solve deeper structural inequalities is fraught with difficulties, from the huge sums needed to the inability to adequately determine the beneficiary class. ${ }^{66}$

In this sense, Peru's TRC made recommentations for collective reparations for traditionally marginalised regions as a result of the long period of violence. ${ }^{67}$ Collective reparations can address past ESRs violations while employed at the same time to improve socioeconomic conditions of communities, for instance, providing public infrastructure and services or funding industry initiatives. On the other hand, attempting to provide reparations for too broad a category of violations will not only be prohibitively expensive but also risky regarding the expectations. Accordingly, reparations of ESRs violations have been focused so far on cases of dispossession of land or other property, which led to denial of livelihood, labour rights, health and other rights. Only recently have there been efforts to compensate or restitute lands taken for tactical or economic reasons within the context of armed conflict, but requiring proof that the dispossession was deliberately induced for political or discriminatory reasons. ${ }^{68}$

Notwithstanding the above mentioned, reparations awarded by the IACtHR have incorporated the realisation of ESRs in innovative ways. Particularly relevant in this sense is the case of Plan de Sánchez Massacre v. Guatemala, ${ }^{69}$ where the Court considered that the massacre 'gravely affected the identity and values of the members of the Maya-Achí people', thus recognizing the infringement of cultural rights and the damage caused to all things that made the

66 For an account of the evolution of Peru's reparations program in light of these concerns, see García-Godos, J., «Victims Reparations in the Peruvian Truth Commission and the Challenge of Historical Interpretation», International Fournal of Transitional fustice, vol.2, no.10, 2008, pp. 63-82.

67 CORREA, C., Reparations in Perú: from recommendations to implementation, ICTJ Report, 2013, pp. $5-7$.

68 DUTHIE, R., «Transitional Justice and Displacement», International fournal of Transitional fustice, vol.5, no.2, 2011, pp. 241-261. In the case of South Africa, for instance, the law required a causal link between the dispossession and racially discriminatory laws and practices.

69 IACtHR, Plan de Sánchez Massacre v. Guatemala, Judgement of 19 November 2004, Series C, No. 116, in particular paras. 81, 100, 104-105, 107 and 110. 
livelihood of the community possible. The Court ordered both individual and collective reparations for pecuniary and non-pecuniary damage..$^{70}$ Additionally, the Court ordered the state to implement certain development programmes, intrinsically related to the enjoyment of ESRs. With those decisions, the Court intended not only to restore the situation ex ante, but also to correct situations which it considered contrary to the spirit of international human rights law. Another relevant case in this sense related to workers' rights is De La Cruz Flores v. Peru, where the IACtHR held that a doctor who was arbitrarily detained had to be reincorporated at the same level as he was before the detention took place. ${ }^{71}$ Similarly, in the case Loayza Tamayo v. Perú, the Court ordered the victim's reincorporation to the teaching service and established that the salary and other benefits should be equivalent to the moment of her detention. ${ }^{72}$

According to Roht-Arriaza, reparations intersect with ESRs as the material reparations offered are both forward and backward looking, aimed at both redressing past harms and transforming lives for the future. While ESRs are often concomitantly violated with the basic $\mathrm{CPRs},{ }^{73}$ they have received little the attention from reparation programmes so far. ${ }^{74}$

\section{III.4. Institutional reform}

According to the commentary on the updated principles to combat impunity 'institutional reform should be of a 'comprehensive' nature for it to be 'a foundation for sustainable justice. ${ }^{\prime 75}$ Consequently, institutional reform

70 The Court awarded $\$ 5,000$ to each victim for pecuniary damage and $\$ 20,000$ to each victim, partly for the damage caused to their culture heritage.

71 IACtHR, De La Cruz Flores v. Perú. Merits, Reparations and Costs. Judgement of 18 November 2004, Serie C No. 115, paras. 169 y 171.

72 IACtHR, Loayza Tamayo v. Perú. Reparations and Costs. Judgement of 27 November 1998, Serie C No. 42, paras. 113/114.

73 For instance, family members of those killed or forcibly disappear suffer, not only the harm of losing a loved one, but also the loss of a breadwinner, the need to flee, the loss of schooling opportunities etc.

74 In this sense it is worth mentioning that the jurisprudence of the Inter-American Court of Human Rights compensates survivors for these lost opportunities through the concept of changes in their 'life's project' (proyecto de vida). This was first introduced in the Loayza Tamayo case and developed in subsequent cases.

75 Orentlicher, D., Report of the Independent Expert to Update the Set of Principles to Combat Impunity, UN Doc. E/CN.4/2005/102 (18 February 2005), para. 66. 
mechanisms should deal both with structural transformations of those who participated in human rights violations and the root causes of conflict or repression in order to prevent further violations. Specifically with regard to ESRs, institutional reform is a key dimension of transitional justice as it has the potential to trigger structural changes. At the same time however it is one of the most under-researched and unexplored areas.

The Comprehensive Peace Agreement between the Government of Nepal and the Communist Party of Nepal signed in November 2006 is a good example of including ESRs through institutional reform mechanisms. The agreement explicitly calls for the establishment of a political system that fully complies with universally accepted human rights (sects. 3.4 and 7.1.2) and ends discrimination (sect. 3.5); and for the protection of the right to education, shelter, food security, social security, health and employment, as well as for land reform (sects. 3.9 and 7.5).$^{76}$ However, the development and implementation of those principles and goals has so far not been as satisfactory as expected. ${ }^{77}$

Similarly, the transitional justice process in the post-apartheid regime in South Africa also required structural reforms in different areas, in which commitment to non-discrimination was essential. The institutional reform there began with the adoption of the Interim Constitution (Act 200 of 1993), which contained a chapter on fundamental rights, including ESRs. The Interim Constitution recognised the justiciability of all fundamental rights without any distinction. ${ }^{78}$ Also, the Truth and Reconciliation Commission in South Africa dealt with institutional reform in different areas. While it did not consider specific violations of ESRs, it emphasized that 'the recognition and protection of socioeconomic rights are crucial to the development and sustaining of a culture of respect of human rights'. ${ }^{79}$ The Commission likewise recognised that businesses and financial institutions should help in the reconstruction by making resources available to those most in need. ${ }^{80}$

76 Comprehensive Peace Agreement between the Government of Nepal and the Communist Party of Nepal (Maoist), (22 November 2006).

77 See i.e, Pasipanodya, T., «A deeper justice: economic and social justice as transitional justice in Nepal», International fournal of Transitional fustice, vol.2, no. 3, 2008, pp. 378-397.

78 Constitutional Principles, number II, «Everyone shall enjoy all universally accepted fundamental rights, freedoms and civil liberties, which shall be provided for and protected by entrenched and justiciable provisions in the Constitution, which shall be drafted after having given due consideration to inter alia the fundamental rights contained in Chapter 3 of this Constitution'.

79 South African Truth and Reconciliation Commission Report, vol. 5, chapter 8, 308.

80 Ibid., pp. 318-320. 
On the other hand, vetting procedures as part of institutional reform are a key tool that can be used to remedy and prevent human rights violations. Vetting is generally understood as the process of ensuring that public officials responsible for gross human rights violations do not continue to serve in state employment. ${ }^{81}$ As Szoke-Burke notes, where breaches of ESRs were linked to the past conflict, vetting those who are guilty of ESRs violations, including non-state actors, can be an effective means of ensuring non-recurrence and of strengthening the rule of law. ${ }^{82}$

The above-mentioned examples and experiences reveal some ways in which different institutional reform measures can be used to address ESRs within the transitional justices process. However, it is important to be aware that institutional reform is a lengthy process, so results might be perceived only in the mid and long term. They will certainly depend on political will and the existence of adequate resources to carry them out.

\section{CONCLUDING THOUGHTS}

Although transitional justice has been traditionally focused on bodily integrity violations, recent claims and debates open the door to include socioeconomic conditions and violations of ESRs within the existing transitional justice mechanisms. However, whether transitional justice should include ESRs and how this inclusion could be articulated is still highly disputed within transitional justice scholarship. In this sense, it should be noted that ESRs are just one element of the socioeconomic dimension of transitional justice, and addressing State failures to respect and protect ESRs is perfectly conceivable within the existing transitional justice tools. While it would be unrealistic to expect that addressing ESRs violations would resolve the full extent of the socioeconomic challenges in transitional justice contexts, ESRs violations should not be longer ignored. Indeed, disregarding ESRs violations in transitional justice processes risks leaving important causes of the violent past unaddressed, so including state failures to respect and protect ESRs according to their particular context and past violent dynamics, could definitely contribute to improve socioeconomic concerns in this regard.

81 ORENTLICHER, supra note 75 at principle 36.a.

82 SzOKE-BuRKe, supra note 2 at 489. 
Several commentators contended, however, that social justice should also be included in transitional justice processes, which led to a new approach so-called transformative justice. This approach, which theoretically implies to provide economic, legal and political justice in an effort to transform state structures, it has been questioned for being thin on conceptual inspiration and making a limited impact in practice. While moving towards the integration of socioeconomic concerns in transitional justice would be desirable, research is still need it in order to examine to what extend this could mean a significant transformative change. Eventually, development projects should be designed and implemented alongside with transitional justice strategies to improve socioeconomic conditions and ESRs enjoyment.

Additionally, this article illustrated how ESRs violations can be effectively addressed with the existing transitional justice mechanisms. TRCs have proved to be a suitable instrument to identify and acknowledge ESRs violations, as well as to provide corresponding recommendations to remedy such violations. In addition, litigation is becoming also an important tool in ending impunity for ESRs violations, not only at regional human rights level, but also at national constitutional courts. Both mechanisms are as well potentially able to identify the role of all perpetrators including non-state actors, which often participated or benefiting from ESRs violations in conflict or repressive regimes. Likewise, reparations can alleviate victims' harm and even contribute to collective transformative effects, although resources are frequently limited due to budgetary constraints. Institutional reform can also contribute to improve general socioeconomic conditions, as well as vetting those who perpetrated or directly benefited from ESRs violations.

This article has also contended that specific criteria grounded in solid theoretical and legal analysis and empirical research must be established to determine which ESRs violations should be addressed and at what priority level in each specific case. To this aim, it would be appropriate to give transitional justice mechanisms wide and comprehensive mandates, so specific priorities and areas of focus can be determined by them at operational level. Once again, limits will depend on the specific context and circumstances, but it seems that a smart mix of mechanisms which work complementarity would be the best option to deal with past ESRs violations in transitional justice processes. Effectively addressing ESRs does ultimately contribute to reinforce the indivisibility of human rights but more importantly, would be crucial to achieve a successful transition and a sustainable peace. 


\section{LIST OF REFERENCES}

Alija FernandeZ, R.A., «La multidimensionalidad de la justicia transicional: un balance entre los límites jurídicos internacionales y los límites de lo jurídico», in J. Bonet Pérez and R. A. Alija Fernández (eds.), Impunidad, derechos bumanos y justicia transicional, Universidad de Deusto, 2009, pp. 93-166.

Arbour, L., «Economic and Social Justice for Societies in Transition», International Law and Politics, vol. 40, no.1, 2007.

CAHILl-RIPley, A., «Foregrounding socio-economic rights in transitional justice: realising justice for violations of economic and social rights», Netherlands Quarterly of Human Rights, vol.32, no. 2 (2014)

Calvet Martínez, E., «La exigibilidad de los derechos económicos, sociales y culturales en situaciones de post-conflicto y en procesos de justicia transicional», in J. Bonet Pérez and R. A. Alija Fernández (eds.), La exigibilidad de los derechos económicos, sociales y culturales en la Sociedad Internacional del siglo XXI: una aproximación jurídica desde el Derecho internacional, Marcial Pons, 2016, pp.199-217.

CARRANZA, R., «Plunder and pain: Should transitional justice engage with corruption and economic crimes?» International fournal of Transitional fustice, vol.2, 2008.

Chega! The report of the Commission for reception, Truth, and Reconciliation in Timor-Leste, Executive summary (2006)

Correa, C., Reparations in Perú: from recommendations to implementation, ICTJ Report, 2013.

De GreIfF, P.; DuthIE, R., Transitional fustice and Development: Making Connections, Social Science Research Council, 2009.

DuthIE, R., «Towards a Development-sensitive Approach to Transitional Justice», International Fournal of Transitional fustice, vol. 2, no. 3, 2008.

- «Transitional Justice, Development, and Economic Violence», in D. N. Sharp (ed.), Fustice and Economic Violence in Transition, Springer, 2014, pp.165-201.

- «Transitional Justice and Displacement», International fournal of Transitional Fustice, vol. 5, no. 2, 2011.

Elster, J., Closing the Books: Transitional fustice in Historical Perspective, Cambridge, Cambridge University Press, 2004.

Garcia-Godos, J., «Victims Reparations in the Peruvian Truth Commission and the Challenge of Historical Interpretation», International Fournal of Transitional Fustice, vol.2, no.10, 2008.

Gready, P.; RobINS, S., «From Transitional to Transformative Justice: A New Agenda for Practice', International fournal of Transitional fustice, vol. 8, no. 3, 2014.

GREADY, P., The Era of Transitional Fustice: The Aftermath of the Truth and Reconciliation Commission in South Africa and Beyond, Routledge, 2010.

Haldemann, F.; Kouassi, R., «Transitional Justice without Economic, Social and Cultural Rights?» in E. Riedel, G. Giacca and C. Golay (eds.), Economic, Social, and Cultural Rights: Contemporary Issues and Challenges, Oxford University Press, 2014, pp. 498-514.

HaYner, P., Unspeakable Trutbs: Transitional fustice and the Challenge of Truth Commissions, Routledge, 2011. 
Final Report of South African Truth and Reconciliation Commission, vol.5, 1998.

IACtHR, De La Cruz Flores v. Perú. Merits, Reparations and Costs, Judgement (ser. C) No. 115 (November 18, 2004)

IACtHR, Ituango Massacres v. Colombia, Preliminary Objections, Merits, Reparations, and Costs, Judgment (ser. C) No. 148 (July 1, 2006)

IACtHR, Loayza Tamayo v. Perú. Reparations and Costs (ser. C) No. 42 (November 27, 1998)

IACtHR, Plan de Sánchez Massacre v. Guatemala, Judgement (ser. C) No. 116 (November 19, 2004)

ICTY, Prosecutor v. Momčilo Krajišnik, No. IT-00-39-T, Trial Chamber, Judgement of 27 September 2006.

ICTY, Prosecutor v. Radoslav Brđanin, No. IT-99-36-T, Trial Chamber, Judgement of 1 September 2004.

KoskA, G., «Corporate accountability in times of transition: the role of restorative justice in the South African Truth and Reconciliation Commission, Restorative Justice», Restorative Fustice. An International fournal, vol. 4, no.1, 2016.

Lambourne, W., «Transformative justice and Peacebuilding», in S. Buckley-Zistel, T. Koloma Beck, C. Braun and F. Mieth (eds.), Transitional fustice Theories, Routledge, 2014, pp. 19-39.

LAPLANTE, L., «Transitional justice and peacebuilding: diagnosing and addressing the socioeconomic roots of violence through a Human Rights Framework», The International Fournal of Transitional fustice, vol. 2, 2008.

Mamdani, M., «Reconciliation without Justice», Southern African Review of Books, vol. 46, 1996.

MANI, R., «Editorial: Dilemmas of expanding transitional justice, or forging the nexus between transitional justice and development», International fournal of Transitional Fustice, vol. 2, 2008.

MCEVOY, K., «Beyond Legalism: Towards a Thicker Understanding of Transitional Justice», fournal of Law and Society, vol. 34, no.4, 2007.

MCGONIGLE LEYH, B., «The Socialisation of Transitional Justice: expanding justice theories within the field», Human Rights and International Legal Discourse, no.1, 2017.

MilleR, Z., «Effects of invisibility: In search of the «economic' in transitional justice», International Fournal of Transitional fustice, vol.2, no. 3, 2008.

Muñoz Nogal, E.; Gómez Isa, F., «iPan, Libertad, Justicia Social! Las revueltas populares de Túnez y Egipto y la defensa de derechos económicos y sociales», in J. Bonet Pérez and R. A. Alija Fernández (ed.), La exigibilidad de los derechos económicos, sociales y culturales en la Sociedad Internacional del siglo XXI: una aproximación jurídica desde el Derecho internacional, Marcial Pons, 2016, pp. 219-241.

Olsen, T.; Payne, L.; Reiter, A., «Transitional Justice in Balance: Comparing Processes, Weighing Efficacy», Human Rights Quarterly, vol. 32, no. 4, 2010.

Oré Aguilar, G.; Gómez Isa, F. (eds.), Rethinking Transitions: Equality and Social fustice in Societies Emerging from Conflict, Intersentia, 2011.

Orentlicher, D., Report of the Independent Expert to Update the Set of Principles to Combat Impunity, UN Doc. E/CN.4/2005/102 (18 February 2005) 
Pasipanodya, T., «A deeper justice: economic and social justice as transitional justice in Nepal», International Journal of Transitional Justice, vol.2, no. 3, 2008.

Roth-Arriaza, N., «Why was the Economic Dimension Missing for So Long in Transitional Justice? An Exploratory Essay», in H. Verbitsky and J. P. Bohoslavsky (ed.), The Economic Accomplices to the Argentine Dictatorship. Outstanding Debts, Cambridge University Press, 2015, pp. 19-28.

ŞAHINKAYA, Y., «The expanded scope of Transitional Justice: Addressing Root Causes of Economic, Social and Cultural Rights Violations', Human Rights Review, vol. III, no. $1,2013$.

SANDOVAL, C.; FILIPINI, L.; VIDAL, R., «Linking Transitional Justice and Corporate Accountability», in S. Michalowski (ed.), Corporate Accountability in the Context of Transitional fustice Michalowski, Routledge, 2013, pp. 9-26.

SCHMID, E.; Nolan, A., «Do No Harm'? Exploring the Scope of Economic and Social Rights in Transitional Justice', The International fournal of Transitional fustice, vol. 27, no.3, 2014.

SCHMID, E., «Liberia's Truth Commission Report: Economic, Social, and Cultural Rights in Transitional Justice', Praxis: The Fletcher fournal of Human Security, vol. XXIV, 2009.

SCSL, Prosecutor v. Issa Hassan Sesay, Morris Kallon and Augustine Gbao, No. SCSL-0415-T, Trial Chamber I, Judgement of 25 February 2009.

Sharp, D.N, «Addressing Economic Violence in Times of Transition: Toward a Positive-Peace Paradigm for Transitional Justice», Fordham International Law fournal, vol. 35 (2012)

Sierra Leone Truth and Reconciliation Commission, «Witness to Truth: Report of the Sierra Leone Truth and Reconciliation Commission», vol. 2. Report Three A, Chapters 1-4, 2004.

Szoke-Burke, S., «Not Only «Context': Why Transitional Justice Programs Can No Longer Ignore Violations of Economic and Social Rights», Texas International Law fournal, vol. 50, no.3, 2015.

TeITEL, R., «Transitional Justice Genealogy», Harvard Human Rights Fournal, vol.16, no.1, 2003.

UE, Council of the European Union, Secretary-General of the European Commission, Joint Staff Working Document: The EU's Framework on support to transitional justice, Doc. SWD 158 final (7 August 2015)

UN, «Human Rights Council Resolution on Transitional Justice and Human Rights', A/ HRC/ RES/12/11 (12 October 2009).

UNGA, «Basic Principles and Guidelines on the Right to a Remedy and Reparations for Victims of Gross Violations of International Human Rights Law and Serious Violations of International Humanitarian Law», A/RES/60/147 (16 December 2005).

UNHRC Report, «Transitional Justice and Economic, Social and Cultural Rights', HR/ PUB/13/5, 2014.

Waldorf, L., «Anticipating the Past: Transitional Justice and Socio-Economic Wrongs», fournal of Social \& Legal Studies, vol. 21, no. 2, 2012. 



\section{DECISIONES DE LOS ÓRGANOS JUDICIALES}


